\title{
INTERFERENSI BAHASA DAERAH KE DALAM BAHASA INDONESIA PADA KARANGAN NARASI SISWA
}

\section{REGIONAL LANGUAGE INTERFERENCE INTO INDONESIAN IN STUDENTS' NARRATIVE COMMENTS}

\author{
Agustin Noer Ovie ${ }^{1 *}$, Anggia Suci Pratiwi ${ }^{2}$, Meiliana Nurfitriani ${ }^{3}$ \\ 1,2,3 Universitas Muhammadiyah Tasikmalaya, Indonesia \\ 1agustinnoerovie@gmail.com \\ 2anggia@umtas.ac.id \\ 3meiliana.nurfitriani@umtas.ac.id
}

DOI: $10.35438 /$ cendekiawan.v3i2.193

\section{Article Info}

Historical Articles

Submitted: 2020-08-11

Revised: 2021-12-14

Issued: 2021-12-29

Keywords: Language Interference, Local

Language, Narrative Essay.

Kata kunci: Interferensi Bahasa, Bahasa Daerah, Karangan Narasi
This study aims to obtain data and information about the object of research. The object of this research is students' narrative essays that focus on the form of regional language interference into Indonesian. This type of research is caulitative research. Data obtained by observation, interview and assignment techniques. Observation and interview techniques are used to find information about the state of the school, while assignment techniques are used to obtain data sources about students' narrative essays. The data source in the form of students' narrative essays was then collected and analyzed. The data that had been collected were analyzed by grouping and describing each according to the type of interference. The results of the analysis are presented with a descriptive method. The results showed that the interference that occurred in the students' narrative essays was in four areas of linguistics, namely: phonology, morphology, lexical, and syntax. Interference that occurs in the field of phonology includes changes in vowel sounds as much as $8 \%$. In the field of morphology, it consists of interference in affixation and repetition of $28 \%$. In the lexical field, the interference that occurs includes three classes of words, namely: nouns, verbs and adjectives as much as $28 \%$.

Abstrak

Penelitian ini bertujuan untuk memperoleh data dan informasi mengenai objek penelitian. Jenis interferensi yang terjadi dideskripsikan secara tekstual sesuai dengan objek penelitian yaitu jenis-jenis interferensi bahasa. Objek pada penelitian ini adalah karangan narasi siswa yang berfokus pada bentuk interferensi bahasa Daerah ke dalam bahasa Indonesia. Jenis penelitian ini adalah penilitian kaulitatif. Data diperoleh dengan teknik observasi, wawancara dan penugasan. Teknik observasi dan wawancara digunakan untuk mencari informasi mengenai keadaan sekolah, sedangkan teknik penugasan digunakan untuk mendapatkan sumber data tentang karangan narasi siswa. Sumber data berupa karangan narasi siswa tersebut kemudian dikumpulkan dan selanjutnya dianalisis. Data yang telah dikumpulkan dianalisis dengan cara pandang dan dideskripsikan masing-masing menurut jenis interferensinya. Hasil analisis disajikan dengan metode deskriptif. Hasil penelitian menunjukkan bahwa interferensi yang terjadi dalam karangan narasi siswa ini terdapat pada empat bidang linguistik, yaitu: fonologi, morfologi, leksikal, dan sintaksis. Interferensi yang terjadi pada bidang fonologi mencakup perubahan bunyi vokal sebanyak $8 \%$. Pada morfologi terdiri atas interferensi pada afiksasi dan perulangan sebanyak 28\%. Pada bidang leksikal, interferensi yang terjadi mencakup tiga kelas kata, yaitu: nomina, verba, dan adjektiva sebanyak $28 \%$. 


\section{PENDAHULUAN}

Bahasa merupakan alat komunikasi bagi manusia untuk menyampaikan pikiran dan perasaan yang dilakukan melalui proses belajar (Atmazaki, 2018). Proses pemerolehan bahasa merupakan proses yang dialami anak sejak pertama kali anak belajar berbicara menggunakan bahasa ibunya (Bahnan, 2019). Berikutnya anak akan memasuki usia Sekolah Dasar, selama periode ini anak-anak diharapkan pada tugas utama mempelajari bahasa tulis. Hal ini dimungkinkan setelah anak-anak menguasai bahasa lisan (Hanum et al., 2020). Perkembangan bahasa anak pada periode usia Sekolah Dasar ini meningkat dari bahasa lisan ke bahasa tulis (Yusuf, 2016).

Bahasa Indonesia merupakan bahasa resmi yang digunakan di dalam lingkungan sekolah untuk berkomunikasi (Atmazaki, 2018). Selain itu di lingkungan tempat tinggalnya siswa juga mendapatkan bahasa Indonesia melalui media yang ada di sekitarnya seperti dari media televisi, radio, surat kabar, dan internet (Jahdiah, 2019). Hal tersebut mengakibatkan siswa menggunakan bahasa Indonesia dan bahasa Jawa secara bergantian. Selain bahasa Indonesia, siswa SDN 04 Cintaratu juga mempelajari bahasa lain yaitu bahasa Sunda, karena desa Cintaratu masih termasuk ke dalam wilayah Jawa Barat.

Dilihat dari letak desa yang berada di perbatasan, dapat disimpulkan bahwa warga desa Cintaratu khususnya siswa di SDN 04 Cintaratu yaitu memiliki kemampuan kebahasaan yang disebabkan karena siswa mampu menguasai dan menggunakan dua bahasa dengan benar dalam berkomunikasi. Dari masing-masing siswa yang berdwibahasa akan timbul gejala yang disebut kontak bahasa. Kontak bahasa dapat terjadi karena dipergunakannya dua bahasa atau lebih oleh penutur yang sama secara bergantian (Dadang, 2020). Adanya kontak bahasa yang terjadi diantara para siswa menyebabkan terjadinya interferensi bahasa karena keduanya saling mempengaruhi antara bahasa daerah (Jawa dan Sunda) dan bahasa Indonesia. Kondisi tersebut dapat menyebabkan terjadinya interferensi bahasa, karena dapat merusak kaidah-kaidah kedua bahasa yang dikuasai. Interferensi merupakan penyimpangan dari norma-norma bahasa yang satu dengan bahasa yang lainnya (Subiyatningsih, 2017).

Selain itu interferensi juga dapat terjadi karena siswa lebih memilih menggunakan bahasa Jawa sebagai alat untuk berkomunikasi (Khoirun Nisa, 2017). Dalam pengantar pembelajaran di sekolah, khususnya dalam pembelajaran bahasa Indonesia guru pun lebih sering menggunakan bahasa Jawa dan bahasa Sunda sebagai bahasa pengantarnya, sehingga perilaku guru tersebut mempengaruhi siswa dalam berkomunikasi. Kebiasaan menggunakan bahasa daerah menyebabkan pemahaman kata-kata dalam bahasa Indonesia siswa lebih rendah dibandingkan pemahaman kata-kata dalam Bahasa Indonesia (Sukmawati et al., 2013).

Berdasarkan hasil observasi yang telah dilakukan terhadap proses pembelajaran Bahasa Indonesia pada siswa kelas V SDN 04 Cintaratu sangat meyakinkan adanya interferensi yang terjadi dalam proses pembelajaran Bahasa Indonesia. Hal tersebut disebabkan adanya alih penggunaan atau sering disebut dengan alih kode dan adanya campur kode. Hal tersebut terjadi karena siswa mencampurkan bahasa Jawa dan bahasa Sunda dalam proses pembelajaran bahasa Indonesia.

Berangkat dari fenomena diatas, yakni interferensi bahasa yang banyak terjadi dilingkungan sekitar kita, baik pada saat keadaan formal maupu informal. Maka penulis melakukan penelitian dengan mengambil judul "Interferensi Bahasa Daerah Ke Dalam Bahasa Indonesia Siswa Kelas V SDN 04 Cintaratu"

\section{METODE}

Jenis penelitian dan strategi yang sesuai untuk penelitian ini adalah deskriptif kualitatif, dalam ranah teks dan bahasa. Jenis penelitian deskriptif tidak dimaksudkan untuk menguji hipotesis tertentu (Hidayat, 2018), tetapi hanya menggambarkan apa adanya tentang keadaan yang ada di lapangan (Handayani, 2020). Penelitian ini tidak dimaksudkan untuk menguji suatu model, metode atau media pembelajaran dalam bahasa Indonesia, akan tetapi mendeskripsikan atau menggambarkan 
secara mendalam tentang bentuk interferensi bahasa daerah ke dalam bahasa Indonesia pada karangan narasi siswa siswa kelas V SDN 04 Cintaratu melalui data yang diperoleh di tempat penelitian. Hasil karangan narasi siswa yang sudah dikumpulkan akan dianalisis oleh peneliti, dan analisis digunakan untuk mengetahui bentuk-bentuk interferensi bahasa daerah yang terdapat di dalamnya. Dalam hal ini, peneliti atau dengan bantuan orang lain merupakan alat pengumpul data yang utama.

Selanjutnya peneliti juga menggunakan desain penelitian deskriptif kualitatif. (Harfiani \& Setiawan, 2019) mengatakan, format desain deskriptif kualitatif banyak memiliki kesamaan dengan desain deskripsi kuantitatif. Untuk penelitian kualitatif deskriptif ranah teks dan bahasa, peneliti menggunakan desain yaitu: (1) Melaksanakan tinjauan pustaka. (2) Menentukan obyek dan informan penelitian. (3) Menentukan apa yang akan diobservasi. (4) Menentukan dokumen yang harus didapatkan. (5) Melakukan pengumpulan data, menggunakan observasi partisipan, melakukan wawancara mendalam; dan melakukan documenter. (6) Menentukan analisis data. (7) Merencanakan pemeriksaan keabsahan data. (8) Melakukan analisis akhir. (9) Membuat laporan akhir penelitian.

Menurut (Rofiah, 2019) "Populasi adalah wilayah generalisasi yang terdiri atas objek/subjek yang mempunyai kualitas dan karakteristik tertentu yang diterapkan oleh pihak peneliti untuk dipelajari dan ditarik kesimpulannya." Sedangkan sampel adalah "Sampel adalah bagian dari jumlah dan karakteristik yang dimiliki oleh populasi tersebut." (Muthmainnah, 2018).

Namun dalam penelitian kualitatif tidak menggunakan istilah populasi, tetapi oleh Spradley dalam (Li et al., 2018) dinamakan "social situation" atau situasi sosial yang terdiri atas tiga elemen yaitu tempat (place), pelaku (actors), dan aktivitas (activity) yang berinteraksi secara sinergis. Jadi situasi sosial yang terjadi pada peneltian ini adalah kedwibahasaan yang terjadi dimasyarakat desa Cintaratu, khususnya di SDN 04 Cintaratu.

Sampel dalam penelitian kualitatif bukan dinamakan responden, tetapi narasumber atau partisipan, informan, teman dan guru dalam penelitian. Jadi sampel pada penelitian ini adalah siswa dan siswa kelas V di SDN 04 Cintaratu yang berjumlah 16 siswa.

\section{HASIL PENELITIAN}

Kegiatan penelitian telah dilaksanakan di SDN 04 Cintaratu, tepatnya pada tanggal 13 Juni 2020. Penelitian ini dilakukan pada 16 siswa kelas V yang berperan sebagai partisipan. Penelitian ini dilakukan untuk mengetahui jenis-jenis interferensi bahasa daerah ke dalam bahasa Indonesia pada karangan narasi siswa kelas V di SDN 04 Cintaratu. Pengumpulan data dapat dilakukan dalam beberapa seting, sumber dan cara. Dalam pengumpulan data, penulis menggunakan beberapa teknik, antara lain yaitu, observasi, wawancara dan penugasan (Astuti, 2019).

Untuk instrument pengumpulan datanya, penelitian ini menggunakan instrument utama yang berupa buman instrument atau peneliti. Peneliti sebagai kunci utama atau instrumen utama dalam menetapkan dan menjalankan penelitian ini dari pencarian data sampai dengan selesainya penganalisisan data. Peneliti menggunakan pengetahuannya untuk mengidentifikasi dan menentukan interferensi yang terdapat dalam objek penelitian. Setelah diidentifikasi kemudian yang dianggap data penelitian dikelompokkan berdasarkan bentuk dan jenis interferensinya. Setelah data terkumpul, selanjutnya dilakukan analisi data,

Penelitian ini menggunakan teknik analisis data Miles dan Huberman. (Heningtyas, 2014) mengemukakan bahwa aktivitas dalam analisis data kualitatif dilakukan secara interaktif dan berlangsung secara terus menerus sampai tuntas dan menyeluruh. Analisis data dalam penelitian kualitatif dilakukan pada saat pengumpulan data berlangsung atau kalimat berbentuk karangan narasi. Setelah data penyusun dikumpulkan dan diurutkan, kemudian diedit dan disusun berdasarkan urutan pembahasan yang telah direncanakan. Selanjutnya melakukan interprestasi secukupnya dalam usaha memahami kenyataan yang ada untuk menarik kesimpulan (Intania, 2020). Setelah dilakukan analisis, 
dapat ditemukan empat jenis interferensi, jenis interferensi yang terjadi dalam karangan narasi siswa ini terdapat pada empat bidang linguistik, yaitu: fonologi, morfologi, leksikal, dan sintaksis.

\section{PEMBAHASAN}

Berdasarkan penelitian yang sudah dilakukan telah ditemukan empat jenis interferensi, yaitu interferensi fonologi, interferensi morfologi, interferensi leksikal, dan interferensi sintaksis. Inteferensi Fonologi, (Kalfika et al., 2013) menyatakan interferensi fonologi terjadi apabila fonemfonem yang digunakan dalam suatu bahasa menyerap dari fonem-fonem bahasa lain. Interferensi fonologi terjadi apabila penutur mengungkapkan kata-kata dari suatu bahasa dengan menyisikpak bunyi-bunyi bahasa dari bahasa lain.

Inteferensi morfologi, (El Karima, 2020) menyatakan Interferensi dalam bidang morfologi dapat terjadi antara lain oada penggunaan unsur-unsur pembentukan kata, pola proses morfologi, dan proses penggalan afiks. (Nugraheni \& Syuhda, 2019) juga mengatakan interferensi morfologi terjadi apabila dalam pembentukan kata sesuatu bahasa menyerap afiks-afiks bahasa lain.Interferensi morfologi diklasifikasikan menjadi dua tipe. Klasifikasi tersebut meliputi yaitu, afiksasi dan perulangan.

Interferensi Leksikal, (Putri et al., 2017) menyatakan Interferensi dalam bidang leksikal terjadi apabila seorang dwibahasawan pada peristiwa tutur memasukkan leksikal pada bahasa pertama ke dalam bahasa kedua atau sebaliknya. Interferensi leksikal dibagi berdasarkan lima kelas kata yaitu: kelas nomina, kelas verba, kelas adjektiva, kelas pronomina, dan kelas numeralia.

Inteferensi Sintaksis, (Susilowati, 2017) menyatakan inteferensi sintaksis anatar lain meliputi penggunaan kata tugas bahasa pertama pada bahasa kedua, pada pola frase. Interferensi sintaksis terjadi pada tataran kalimat, yakni berupa tata kalimat atau pola penyusunan kalimat.Interferensi ini terjadi karena pemindahan morfem (kata) bahasa pertama ke dalam pemakaian bahasa kedua.Hal ini dapat juga terjadi perluasan pemakaian kata bahasa pertama, yakni memperluas makna kata yang sudah ada, sehingga kata dasar memperoleh kata baru atau bahkan gabungan dari kedua kemungkinan di atas. Interferensi kata dasar terjadi apabila seorang penutur bahasa Indonesia menguasai bahasa daerah dengan baik, sehingga dalam percakapannya sering terselip kata-kata bahasa daerah, sehingga sering terjebak dalam interferensi.

Berikut adalah presentase jenis interferensi yang terdapat pada karangan narasi siswa kelas $\mathrm{V}$ SDN 04 Cintaratu.

Tabel 1. Jenis interferensi dan presentasinya

\begin{tabular}{llll}
\hline No & Jenis Interferensi & Jumlah & $\begin{array}{l}\text { Presen } \\
\text { tase }\end{array}$ \\
\hline 1. & Interferensi Fonologi & 2 & $8 \%$ \\
\hline 2. & Interferensi Mordologi & 7 & $28 \%$ \\
\hline 3. & Interferensi Leksikal & 7 & $28 \%$ \\
\hline 4. & Interferensi Sintaksis & 9 & $36 \%$ \\
\hline Jumlah & 25 & \\
\hline
\end{tabular}

Melihat tabel 1, 16 karangan narasi siswa kelas V SDN 04 Cintaratu yang telah dikumpulkan dan dianalisis, ditemukan 25 kasus interferensi bahasa. Jenis interferensi yang terjadi dalam karangan narasi siswa ini terdapat pada empat bidang linguistik, yaitu: fonologi, morfologi, leksikal, dan sintaksis. Interferensi yang terjadi pada bidang fonologi meliputi perubahan bunyi vokal sebanyak $8 \%$. Pada bidang morfologi sendiri terdiri atas interferensi pada afiksasi dan perulangan sebanyak 28\%. Pada bidang leksikal, interferensi yang terjadi mencakup tiga kelas kata, yaitu: nomina, verba, dan adjektiva sebanyak $28 \%$. Kemudian pada bidang sintaksis pada pola frasa dan kalimat mengasilkan sebanyak 36\%. 


\section{SIMPULAN}

Berdasarkan penelitian yang sudah dilakukan, maka dapat disimpulkan bahwa masih banyak terjadi interferensi yang dilakukan oleh siswa. Hal ini bisa terjadi karena siswa merupakan dwibahasawan. Bentuk-bentuk interferensi tersebut mengakibatkan pemakaian bahasa daerah mempengaruhi pemakaian bahasa Indonesia. Berdasarkan 16 karangan narasi siswa kelas V SDN 04 Cintaratu yang telah dikumpulkan dan dianalisis, ditemukan 25 kasus interferensi bahasa. Jenis interferensi yang terjadi dalam karangan narasi siswa ini terdapat pada empat bidang linguistik, yaitu: fonologi, morfologi, leksikal, dan sintaksis. Interferensi yang terjadi pada bidang fonologi meliputi perubahan bunyi vokal sebanyak $8 \%$. Pada bidang morfologi sendiri terdiri atas interferensi pada afiksasi dan perulangan sebanyak 28\%. Pada bidang leksikal, interferensi yang terjadi mencakup tiga kelas kata, yaitu: nomina, verba, dan adjektiva sebanyak 28\%. Kemudian pada bidang sintaksis pada pola frasa dan kalimat mengasilkan sebanyak 36\%.

\section{REFERENSI}

Astuti, P. (2019). Upaya Meningkatkan Hasil Belajar Ips Siswa Kelas Vi Sd Negeri 7 Sungailiat Kabupaten Bangka Tentang Perkembangan Sistem Administrasi Wilayah Indonesia Melalui Model Pembelajaran Kooperatif Tipe Picture and Picture. Cendekiawan, 1(1), 29-34. https://doi.org/10.35438/cendekiawan.v1i1.156

Atmazaki. (2018). Pembelajaran Bahasa Indonesia Berbasis Teks. Jurnal Ilmiah Kebudayaan Sintesis, 11(1), 1-11.

Bahnan, R. (2019). Penggunaan Media Video Untuk Meningkatkan Hasil Belajar Siswa Tentang Kompetensi Dasar Menirukan Pembacaan Pantun Anak Di Kelas Iv Sd Negeri 26 Sungailiat. Cendekiawan, 1(1), 13-19. https://doi.org/10.35438/cendekiawan.v1i1.154

Dadang. (2020). Analysis of the Application of Paragraph Exchange Technique in Writing Student Essays (Case Study in SD Negeri 4 Cipedes). Cendekiawan, 2(1), 28-40. https://doi.org/10.35438/cendekiawan.v2i1.175

El Karima, A. S. (2020). Interferensi Fonologis Bahasa Inggris dalam Video Youtube "Egyptian Woman Has A Serious Message for Obama." Jurnalistrendi: Jurnal Linguistik, Sastra, Dan Pendidikan, 5(2), 107-115. https://doi.org/10.51673/jurnalistrendi.v5i2.345

Handayani, F. (2020). Building Students' Critical Thinking Skills through STEM-Based Digital Literacy during the Pandemic Period Covid 19. Cendekiawan, 2(2), 69-74. https://doi.org/https://doi.org/10.35438/cendekiawan.v2i2.184

Hanum, F., Harahap, N. J., Hsb, E. R., Nirmala, M., Hasibuan, S., Labuhanbatu, U., Tinggi, P., \& Globalisasi, E. (2020). Pembelajaran Mata Kuliah Bahasa Indonesia. Jurnal Education and Development Institut Pendidikan Tapanuli Selatan, 8(3), 33-36.

Harfiani, Ri., \& Setiawan, H. R. (2019). A Modification of Daily Learning Flow in Inclusive Education Programs. Cendekiawan, 10-15. https://doi.org/10.35438/cendekiawan.v1i2.160

Heningtyas, M. A. (2014). Peran Pemerintah Dan Masyarakat Dalam Upaya Pengembangan Pendidikan Nonformal (Studi Kasus: Eksistensi "Kampung Inggris" Kabupaten Kediri). Jurnal Administrasi Publik Mahasiswa Universitas Brawijaya, 2(2), 264-268.

Hidayat. (2018). Pelaksanaan Pembelajaran Tematik Di Sekolah Dasar Islam Terpadu Izzuddin Palembang. Tarbiyah Wa Ta'lim: Jurnal Penelitian Pendidikan \& Pembelajaran, 5(2), 56-65. 
Intania, H. B. dan. (2020). Interaksi Simbolik dan Imaji Religious dalam Membangun Citra Pondok Pesantren Nurul Jadid Hasan. ATTHULAB: Islamic Religion Teaching \& Learning Journa, 5(1), $71-$ 85. https://doi.org/http://dx.doi.org/10.15575/ath.v5i1.7317

Jahdiah, J. (2019). Penggunaan Bahasa Indonesia Pada Media Luar Ruang Di Kalimantan Selatan. GENTA BAHTERA: Jurnal Ilmiah Kebahasaan Dan Kesastraan, 4(2), 115-128. https://doi.org/10.47269/gb.v4i2.58

Kalfika, K. D., Wardani, A., Gosong, M., Artawan, G., \& Ganesha, U. P. (2013). Sikap Bahasa Siswa Terhadap Bahasa Indonesia: Studi Kasus Di SMA Negeri 1 Singaraja. E-Journal Program Pascasarjana Universitas Pendidikan Ganesha, 2(1). file:///C:/Users/Dell/Documents/886-Article Text-2693-1-10-20151208 (2).pdf

Khoirun Nisa, I. S. (2017). Kesalahan Penggunaan Bahasa Indonesia Dalam Teks Terjemahan Mahasiswa. Jurnal Kajian Bahasa, Sastra Indonesia, Dan Pembelajarannya, 1(1), 1-13.

Li, S., Yamaguchi, S., \& Takada, J. (2018). Understanding factors affecting primary school teachers' use of ICT for student-centered education in Mongolia. International Journal of Education and Development Using Information and Communication Technology (IJEDICT), 14(1), 103-117. http:/ /ijedict.dec.uwi.edu/viewarticle.php?id=2381

Muthmainnah, S. N. (2018). Gaya Mengajar Guru Pemula Dan Guru Profesional Dalam Pembelajaran Matematika Smp Di Klaten Teaching Styles of Novice Teachers and Professional Teachers of Mathematics in Junior Secondary School in Klaten. Jurnal Pendidikan Dan Kebudayaan, 3((2)), 202-216.

Nugraheni, A. S., \& Syuhda, N. (2019). The Interference of Malay Language Towards Indonesian Language. Lingua Didaktik.a, 13(1), 11-25. https://doi.org/10.24036/ld.v13i1.31974

Putri, N. E., Widodo, M., \& Suyanto, E. (2017). Interferensi Leksikal Bahasa Jawa ke dalam Bahasa Indonesia pada Karangan Siswa. Jurnal Kata (Bahasa, Sastra, Dan Pembelajaranya), 2(3), 1-8.

Rofiah, A. (2019). Implementasi Program Pendidikan Karakter Dan Program Gerakan Literasi Sekolah Dalam Membentuk Sikap Kemandirian Belajar Siswa Di Sdn Percobaan 2 Dan Sd Muhammadiyah Sapen. G-Couns: Jurnal Bimbingan Dan Konseling, 3(2), 172-180. https://doi.org/10.31316/g.couns.v3i2.310

Subiyatningsih, F. (2017). Sikap Bahasa Remaja: Kasus Pemakaian Bahasa Indonesia Dalam Rubrik "Deteksi" Jawa Pos. Madah: Jurnal Bahasa Dan Sastra, 7(2), 147. https://doi.org/10.31503/madah.v7i2.424

Sukmawati, Nurhayati, \& Iswary, E. (2013). Penggunaan Bahasa Indonesia pada Informasi Layanan Umum dan Layanan Niaga di Kota Ksendari. Jurnal Bahasa Dan Sastra, 2(1), 3-4.

Susilowati, D. (2017). Aktualisasi Interferensi Bahasa Daerah Dalam Bertutur Kata Pada Pembelajaran Bahasa Indonesia Di Sekolah. Jurnal Ilmiah Edunomika, 1(02), 64-65. https://doi.org/10.29040/jie.v1i02.149

Yusuf, E. B. (2016). Perkembangan dan Pemerolehan Bahasa Anak. Yin Yang: Jurnal Studi Islam, Gender Dan Anak, $11(01), \quad 50$. http://ejournal.iainpurwokerto.ac.id/index.php/yinyang/article/view/826 